Asian J. Med. Biol. Res. 2018, 4 (1), 14-20; doi: 10.3329/ajmbr.v4i1.36816

\author{
Asian Journal of \\ Medical and Biological Research \\ ISSN 2411-4472 (Print) 2412-5571 (Online) \\ www.ebupress.com/journal/ajmbr
}

\title{
Article \\ Epidemiology of duck as reservoir of Avian Influenza Virus in Bangladesh
}

Md. Zakir Hassan ${ }^{1 *}$, Md. Mamunur Rahman ${ }^{2}$, Bidhan Chandra Das $^{3}$, Md. Al Amin ${ }^{3}$, Salma Sultana ${ }^{4}$, Humaira Ferdouse ${ }^{5}$, Md. Jaber ${ }^{6}$, Md. Shajedur Rahman ${ }^{7}$ and Md. Fazlul Hoque ${ }^{7}$

${ }^{1}$ National Reference Laboratory for Avian Influenza (OIE Reference Laboratory), Animal Health Research Division, Bangladesh Livestock Research Institute (BLRI), Savar, Dhaka, Bangladesh

${ }^{2}$ Conservation and Improvement of Native Sheep through Community \& Commercial Farming Project, Goat \& Sheep Production Research Division, BLRI, Savar, Dhaka, Bangladesh

${ }^{3}$ Central Disease Investigation Laboratory, Dept. of Livestock Services, Bangladesh

${ }^{4}$ Department of Physiology, Bangladesh Agricultural University, Mymensingh-2022, Bangladesh

${ }^{5}$ Dept. of English, Sirajganj Govt. College, National University, Bangladesh

${ }^{6}$ Upazila Livestock Office, Bajitpur, Dept. of Livestock Services, Kishoreganj, Bangladesh

${ }^{7}$ Department of Medicine, Surgery \& Obstetrics, Hajee Mohammad Danesh Science \& Technology University, Dinajpur-5200, Bangladesh

*Corresponding author: Md. Zakir Hassan, Scientific Officer, National Reference Laboratory for Avian Influenza (OIE Reference Laboratory), Animal Health Research Division, Bangladesh Livestock Research Institute (BLRI), Savar, Dhaka, Mobile: +8801737840328; Email: zhtitas@ gmail.com, zakir.vet@blri.gov.bd

Received: 21 February 2018/Accepted: 15 March 2018/ Published: 29 March 2018

Abstract: This research work was conducted to detect the prevalence and incidence of Avian Influenza Virus (AIV) in Duck at hoar area of Kishorganj district in Bangladesh. The study period was July 2013 to December 2013 and the molecular work was done in Central Disease Investigation Laboratory (CDIL), Dhaka. A total number of 736 blood serum sample and 150 cloacal swab sample were collected from asymptomatic semi scavenging duck above 4 month of age. Blood serum sample was tested to detect the prevalence of Avian Influenza Virus A (AIV) specific antibody through indirect Enzyme Linked Immunosorbent Essay (ELISA) and cloacal sample was tested to detect the incidence of AIV through real time Polymerase Chain reaction (PCR). A total number of 736 blood serum sample were tested in which 684 is positive (+ve) of Avian Influenza type A antibody and 52 are negative (-ve) of Avian Influenza type A. The prevalence rate was $92.93 \%$. The tested result shown that prevalence rate was in 4-6 month of age as $93.96 \%$, as 7-9 month of age as $92.92 \%$ and in 10-12 month of age as $91.91 \%$. A total number of 15 pooling sample from 75 cloacal samples was conducted for detection of AIV that shed in environment. After calculating the result through real time Reverse Transcription (RT) - PCR, it was shown that 2 pooling sample was positive (13.33\%) for AIV and 13 pooling sample was negative $(86.87 \%)$ for AIV. So incidence rate was $13.33 \%$ for AIV. This duck can transmit the AIV in the surrounding poultry population and clinical outbreaks may occur. After analysis of ELISA \& PCR result it was shown that duck act as a natural reservoir of AIV in Bangladesh.

Keywords: AIV; duck; ELISA; PCR; natural reservoir; Bangladesh

\section{Introduction}

There are many haors, bills, lagoons, lakes and marsh land in Bangladesh which are used for duck rearing. Domestic ducks are in close contact with poultry, livestock and humans in Bangladesh. Duck farming has been an important contributor to high pathogenic avian influenza (HPAI) virus in poultry industry in Southeast Asia including Bangladesh (Gilbert et al., 2006). There are about 320.63 million poultry population in Bangladesh in which 52.24 million are duck population and producing around 120 million egg and 1363 tons meat per day (Livestock Economy, DLS, BD, 2016-17). Avian influenza refers to the disease caused by infection with avian 
(bird) influenza (flu) Type A viruses. These viruses occur naturally among wild aquatic birds worldwide and can infect domestic poultry and other birds. Influenza viruses hold under the family of Orthomyxoviridae and there are four types of influenza viruses: A, B, C and D. Wild aquatic birds and free ranging domestic ducks are the natural hosts for influenza type A viruses. Influenza A viruses are divided into two subtypes on the basis of two proteins on the surface of the virus: Hemagglutinin (HA) and Neuraminidase (NA) (CDC, 2017). The first outbreaks of avian influenza virus were occurred in poultry and wildlife in 2003 in China. In Bangladesh first outbreak in poultry was declared through Government on 22 March 2007 from Animal Health Research Division, Bangladesh Livestock Research Institute (BLRI), Savar, Dhaka (2nd National Avian and Pandemic Influenza Preparedness and Response Plan, Bangladesh 2009-2011). Wild aquatic birds, under the order of Anseriformes (ducks and geese) and Charadriiformes (gulls and shorebirds), are the natural reservoir of all influenza A viruses (Fouchier et al., 2003). Ducks are the natural reservoir of influenza A virus and play the main role for $\mathrm{H} 5 \mathrm{~N} 1$ and serve as re-assortment vessels for-emerging new subtypes of AIV between birds to human (Khatun et al., 2013). Asymptomatic Ducks play a complex and vital role in the biology of AIV and can shed to the environment through faeces (Songserm et al., 2006). Avian influenza A viruses are very contagious viruses can sicken and even kill certain domesticated bird species including chickens, ducks, and turkeys (Alam et al., 2010). Infected birds can shed avian influenza A viruses in their saliva, nasal secretions, and feces (Giasuddin et al., 2011). On the basis of importance of duck in maintenance of AIV in the environment the objectives of the research work was to detect the prevalence and incidence of Avian Influenza Virus (AIV) in Duck at hoar area of Kishorganj district in Bangladesh.

\section{Materials and Methods}

\subsection{Study area}

On the basis of duck population samples were collected from hoar area at Kishoreganj District of Bangladesh.

\subsection{Sample Collection}

There were 736 blood serum samples and 150 cloacal sample was collected from asymptomatic semiscavenzing duck population from July 2013 to December 2013. Blood samples were collected randomly and aseptically from duck. About 2 to $2.5 \mathrm{ml}$ of blood sample was taken from each duck from wing vein using sterile $3 \mathrm{ml}$ disposable plastic syringe without anticoagulant and were kept in flask containing ice pack. Cloacal sample was collected by using cotton swabs form the vent of duck. The sterilized cotton swab was introduce through the cloaca, gently rubbing and remain in VTM media after broken the wooden shaft. The Cotton swabs with Virus Transport Media (VTM) were stored in ice back containing cool box.

\subsection{Separation of serum from blood samples}

After collection of blood sample was allowed to $45^{0}$ angles around 1 hour for clotting. After clotting, serum was separated into eppendorf tube, numbering and packaging was done and stored in ice back containing cool box.After collection of blood sera and cloacal sample were carried to the Central Disease Investigation Laboratory (CDIL), 48 Kazi -Alauddin Road, Dhaka -1000, Bangladesh. Then the serum and cloacal sample was strored at $-80^{\circ} \mathrm{C}$ for further activity.

\subsection{Sample preparation for molecular study}

After collection of sera and cloacal sample from $-80^{\circ} \mathrm{C}$ temperature, it was allowed to at room temperature (25$26^{\circ} \mathrm{C}$ ). Then serum sample was decanted in centrifuge tube and centrifuge at 2,500 rpm for 5 minutes for more clear serum separation. These sera sample was allowed to indirect ELISA for detection of avian influenza type A virus specific antibody and cloacal sample was allowed to pooling to detect incidence of AIV type A by real time PCR.

\subsection{Indirect ELISA for AIV type A specific antibody}

The avian influenza virus antibody test ELISA kit was measure the amount of antibody to AIV in the serum of duck. 96-well polystyrene Microtitre plates were pre-coated with AI viral antigen. Al specific antibody forms a complex with the coated antigen. The sera samples were subjected to indirect ELISA using commercial AIV Antibody Test Kit, ELISA (IDEXX AL Multi S-Screen Test Kit, US) as per manufacturer's instructions. All supplied reagent and chemical in AI ELISA test kit was came to $18-26^{\circ} \mathrm{C}$ temperature and mixed gently inverting and swirling was done. Antigen coated plate was recorded in sample position. A $100 \mu$ l of undiluted positive control (containing high percentage of avian Influenza Type A antibody) was dispensed into AIV ELISA wells A1 and B1. A $100 \mu$ of undiluted negative control (containing RNA free water) was dispensed 
into AIV ELISA wells C1 and D1. Controls were ready to use; no dilution was required for each plate.. Controls were ready to use; no dilution was required for each plate. After dispensing $100 \mu \mathrm{l}$ of each diluted sample into the appropriate wells, it was then incubated at $18-26^{\circ} \mathrm{C}$ temperature for 60 minutes. The liquid contents of all wells were aspirated into the supplied wash solution. Each well was washed with approximately $350 \mu \mathrm{l}$ of detergent buffered wash solution three times. Plate drying was avoided between plate washings and prior to the addition of conjugate reagent. $100 \mu \mathrm{l}$ of enzyme labelled antigens conjugate was dispensed into each well. Then it was incubated at $18-26^{\circ} \mathrm{C}$ temperature for 30 minutes. Each well was washed with approximately $350 \mu 1$ of detergent buffered wash solution three times. $100 \mu \mathrm{l}$ of peroxidase substrate solution was dispensed into each test plate well. Then it was incubated at room at $18-26^{\circ} \mathrm{C}$ temperature for 30 minutes. $100 \mu$ lof stop solution was dispensed into each well of the test plate to stop the enzyme- substrate reaction and thereby the color development. A yellow color was developed in positive case of anti- AIV antibody in the sample. The intensity of color developed was measured by determination of OD (optical density) value of tested samples using an ELISA reader at $650 \mathrm{~nm}$ filter and the result was calculated by the following calculations.

So Prevalence of Avian Influenza type A in Duck $=\underline{\text { Total Number of Positive Case }} \times 100 \%$ Total Number of Tested Sample

\subsection{Calculations}

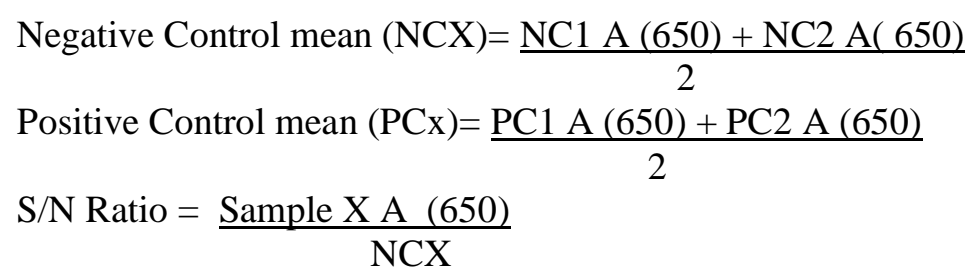

\subsection{Data Management}

xChekPlus* software was used to AIV specific antibody ELISA data management. These xChekPlus software was interfaced to read the plate and send the optical densities to the computer and calculate the results were done.

\subsection{Result interpretation for ELISA}

Samples with an $\mathrm{S} / \mathrm{N}$ Ratio $\geq 0.50$ were considered negative for the presence of $\mathrm{Al}$ antibodies Samples with $\mathrm{S} / \mathrm{N}$ values $<0.50$ were considered $\mathrm{Al}$ antibody positive. Heat inactivation of samples may adversely affect results was avoided.

\subsection{Real Time RT-PCR}

\subsubsection{Preparation of sample}

Total sample of cloacal sample was 150 . Each 10 samples were mixed for pooling. AIV is a viral RNA, so Reverse Transcriptase Polymerase Chain Reaction (Real time RT- PCR) technique was used to detect the incidence of AIV. So total number of pooling sample was

\subsubsection{RNA Extraction}

ANIGEN (king Fisher Mag Max-96 Total RNA) Isolation Protocol was used for extraction of viral RNA. $150 \mu 1$ of pooling cloacal sample and $250 \mu \mathrm{l}$ binding buffer -1 were taken, vortexing for 15 second and incubated for 10 min at $25-26{ }^{\circ} \mathrm{C}$ temperature. Then $350 \mu 1$ binding buffer -2 was added and mixed properly by vortexing. Spin column was placed in a provided $2 \mathrm{ml}$ collection tube and loading was done in the spin column and centrifuge at 13000 RPM for $1 \mathrm{~min}$. The solution was discarded in collection tube and placed in the spin column. Again 500 $\mu \mathrm{l}$ of washing buffer 1 was taken to spin column and centrifuge for $1 \mathrm{~min}$. at $13000 \mathrm{rpm}$. Then the solution was discarded in the spin column. $500 \mu \mathrm{l}$ of washing buffer 2 was taken to column and centrifuge for 1 minute at $13000 \mathrm{rpm}$. Then the solution was discarded in collection tube and placed the column back to $2 \mathrm{ml}$ collection tube and centrifuge for 1 minute at $13000 \mathrm{rpm}$. The column was placed in a RNAse -free $1.5 \mathrm{ml}$ tube and add 30 ul of elution buffer. Then incubation was done at $25-26{ }^{\circ} \mathrm{C}$ temperature for 1 minute at $13000 \mathrm{rpm}$ and stored the RNA product at $-20{ }^{\circ} \mathrm{C}$. rRT-PCR primer and probe sequences of AIV type A was used for M gene (Table 1).This RNA product was mixed in master mixture preparation $(25 \mu \mathrm{l})$ for real time RT- PCR (Table 2). A collection tube was taken and mixed all the common ingredients. Sample tube arrangement was done on PCR 
machine and maintained Thermal Profile and Primer Probe Sequence. To detect the incidence of AIV two RNA positive controls and one negative control was used. For real time RT- PCR iQ5.exe (v2.1.94.617) (OSMicrosoft Windows NT5.1.2600.0. Service Pack 3, CLR-1.1.4322.573, Culture-en-US was used. Thermal profile was $45.0^{\circ} \mathrm{C}$ for 60 minutes at $1^{\text {st }}$ step, $95^{\circ} \mathrm{C}$ for 60 minutes in $2^{\text {nd }}$ step, $94^{\circ} \mathrm{C} 30$ minutes in $3^{\text {rd }}$ step and $60{ }^{0} \mathrm{C}$ for 30 minutes in $4^{\text {th }}$ step. PCR Base Line Subtracted Curve Fit Data (PCR Quantification) data was shown in Figure 1. Among the PCR arrangement G3 and H3 were positive control, and A4 was negative control. Auto calculated threshold value was 66.98 and user defined threshold value was $66.98 . \mathrm{C}_{\mathrm{t}}$ values are inversed to the amount of nucleic acid that was present in the pooling sample. In positive control G3 and H3, $\mathrm{C}_{\mathrm{t}}$ values were 17.90 and 31.59 and in negative control $\mathrm{A} 4, \mathrm{C}_{\mathrm{t}}$ values were Nil. In tested sample B2 \& B3 is positive result (+ve), $\mathrm{C}_{\mathrm{t}}$ values were 30.79 and 31.10 . On the other hand other pooling sample shown negative and the $\mathrm{C}_{\mathrm{t}}$ values were above 32.00 for avian influenza viral RNA (Figure 1).

\section{Results and Discussion}

The presence of antibody of Avian Influenza type A in duck was estimated through commercial AIV Antibody Test Kit, ELISA (IDEXX AL Multi S-Screen Test Kit, US) per manufacturer's instructions. Total number of 736 blood serum sample were tested in which 684 is positive (+ve) of Avian Influenza type A antibody and 52 are negative (-ve) of Avian Influenza type A. The prevalence rate was $92.93 \%$, it is a higher rate due to duck remain in flock condition and haor water act as high contamination source and thus duck act as natural reservoir host for Avian Influenza type A (Showing in table 3). This might be that the ducks were exposed to natural infections with low virulent AIV, as wild and domestic ducks are potent carriers of the virus. (Vander et al., 2003). This result also similar to the result of Zakir et al., 2015 that was $90.21 \%$. The test result shown that highest prevalence rate was in 4-6 month of age as $93.96 \%$, as 7-9 month of age as $92.92 \%$ and in 10-12 month of age as $91.91 \%$ (Shown in Table 3). Antibody against Avian influenza may be found at any age (OIE, 2003) of birds. Waterfowl are the natural reservoir of avian influenza viruses and ducks may play a role in the maintenance of avian influenza type A (Zakir et al., 2015). The prevalence of AIV type A antibody was $92.91 \%$ which were higher rate than Khatun et al. (2013). The domestic duck may get infection from village sided river where the wild water birds are mixed together (Senne et al. 2003). ANIGEN (king Fisher Mag Max-96 Total RNA) Isolation Protocol was used for extraction of viral RNA and proceed to real time RT-PCR for detection of AIV. Here conduction of 15 pooling sample from 75 cloacal sample for detection of AIV shed in environment. After calculating the result through real time RT- PCR iQ5.exe (v2.1.94.617) software it was shown that 2 pooling sample was positive (13.33\%) for AIV and 13 pooling sample was negative( $86.87 \%$ ) for AIV (Shown in Figure $1 \& 2$ ). So incidence rate was $13.33 \%$ for AIV. After calculating the PCR positive result it was seen that Avian Influenza Virus type A antibody containing duck shed avian influenza virus in the environment through faeces, although the duck were clinically asymptomatic. This result also similar to the result of Zakir $e t$ al., 2015. The overall incidence of avian influenza type A was $13.33 \%$ which was slightly lower than the result of Khatun et al. (2013) that was $22.05 \%$ for swab samples in ducks. Avian Influenza Virus can remain in the environment and has possibility to infect surrounding poultry and other birds (Islam et al., 2011). In Bangladesh millions of migratory waterfowls were found during winter season surrounding the haor and marsh area. Ducks and migratory bird are asymptomatically infected with AIV during sharing the same water bodies. This factor may contribute to the infection to the native and commercial poultry industry (Alexander, 2003; De Marco et $a l ., 2003)$. This result also revealed that migratory birds and domestic ducks in haor area played an important role in the emergence novel genotype of highly pathogenic avian influenza virus (AIV) (Barman et al., 2017). Ducks are the natural reservoir of influenza A virus (Khatun et al., 2013) that strongly support this research work.

Table 1. Showing the rRT-PCR primer and probe sequences of AIV type A.

\begin{tabular}{lll}
\hline Primer/probe name & Sequence & Reference \\
\hline $\mathrm{M}+25$ & 5'AGA TGA GTC TTC TAA CCG AGG TCG-3' $^{\prime}$ 'AG & Spackman et al. (2003) \\
M-124 & 5'-TGC AAA AAC ATC TTC AAG TCT CTG-3' & Spackman et al. (2003) \\
M+64 & 5'-FAM-TCA GGC CCC CTC AAA GCC GA-TAMRA-3' & Spackman et al. (2003) \\
\hline
\end{tabular}


Table 2. Showing the ingredients for Master Mix Preparation.

\begin{tabular}{ll}
\hline Component & Volume/ reaction \\
\hline RT-PCR buffer & $12.5 \mu \mathrm{l}$ \\
Forward primer for specific type & $0.5 \mu \mathrm{l}$ \\
Reverse primer for specific type & $0.5 \mu \mathrm{l}$ \\
Probe & $0.5 \mu \mathrm{l}$ \\
Enzyme mix & $1.0 \mu \mathrm{l}$ \\
RNA free water & $2.0 \mu \mathrm{l}$ \\
RNA template & $8.0 \mu \mathrm{l}$ \\
Total & $\mathbf{2 5} \boldsymbol{\mu l}$ \\
\hline
\end{tabular}

Table 3. Showing the prevalence of AIV type A in duck.

\begin{tabular}{lllllll}
\hline Age & Total Sample & $\begin{array}{l}\text { Test } \\
\text { Positive(+ve) }\end{array}$ & $\begin{array}{l}\text { Percentage } \\
\text { Positive }\end{array}$ & $\begin{array}{l}\text { of } \\
\text { Test Negative } \\
\text { (-ve) }\end{array}$ & $\begin{array}{l}\text { Percentage } \\
\text { Negative }\end{array}$ \\
\hline 4-6 Month & 310 & 291 & 93.96 & 19 & 6.04 \\
7-9 Month & 224 & 208 & 92.92 & 16 & 7.08 \\
10-12 Month & 202 & 185 & 91.91 & 17 & 8.08 \\
Total & $\mathbf{7 3 6}$ & $\mathbf{6 8 4}$ & $\mathbf{9 2 . 9 3}$ & $\mathbf{5 2}$ & $\mathbf{7 . 0 7}$ \\
\hline
\end{tabular}

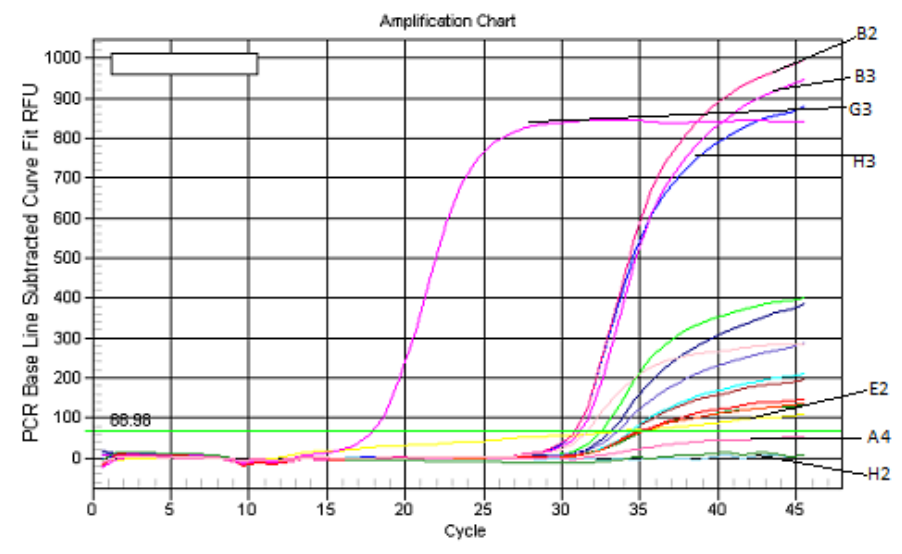

Figure 1. Showing the PCR Quantification data.

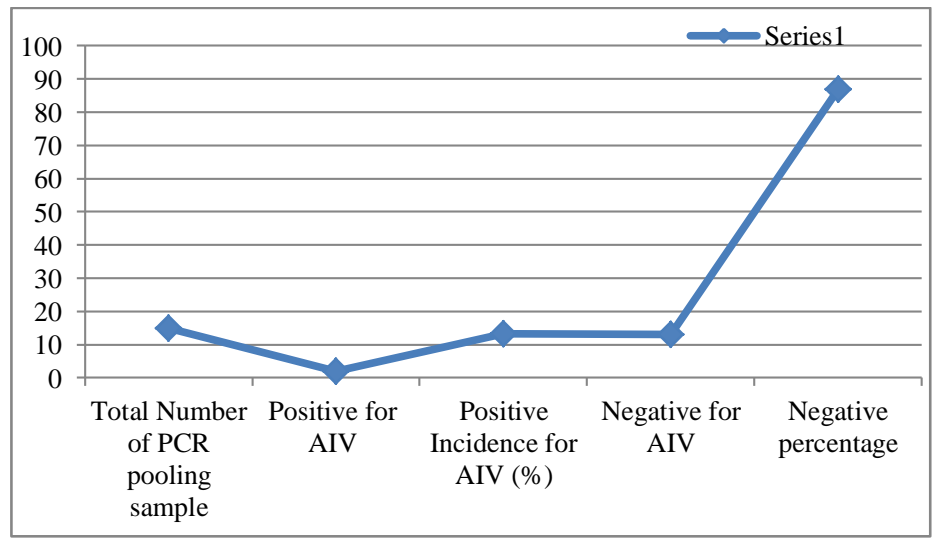

Figure 2. Showing the incidence of AIV in duck. 


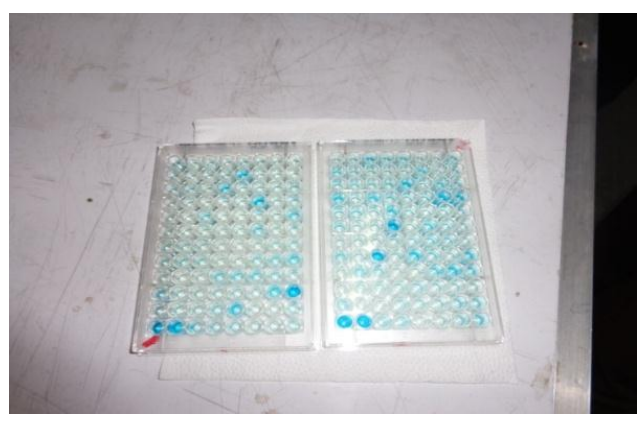

Figure 3. ELISA kit (ELISA well) after using TMB substrate.

\section{Conclusions}

We can say that duck acts as natural reservoir for Avian influenza virus (AIV) type A in Bangladesh. Ducks are natural free ranging birds that moved in marshy environment and infected with AIV asymptomatically but also shed AIV in the environment. Haor area and ducks are ecologically significant for the epidemiology of Avian Influenza virus in Bangladesh.

\section{Acknowledgements}

We would like express our gratitude to Central Disease Investigation Laboratory (CDIL), 48 Kazi Alauddin Road to execute this research work.

\section{Conflict of interest}

None to declare.

\section{References}

Alam J, M Giasuddin, MA Samad and MJFA Taimur, 2010. Recent evidence of Avian Influenza in Bangladesh: a review. Worlds Poult. Sci. J., 66: 455-464.

Alexander F, 2003. Report on avian influenza in the Eastern Hemisphere during. Avian Dis., 47: 792-797.

Avian influenza in Birds, 2017. Centers for Disease Control and Prevention, National Center for Immunization and Respiratory Diseases (NCIRD)

Avian Influenza, 2014. World organization for animal health (OIE). www.oie.int/fileadmin/Home/eng/ Animal_Health_in_the_World/docs/pdf/Disease_cards/HPAI.pdf

Barman S, AM Petkova, MK Hasan, S Akhtar, RE Shesheny, JCM Turner, J Franks, D Walker, J Seiler, K Friedman, L Kercher, T Jeevan, D Darnell, G Kayali, LJ Engel, P McKenzie, S Krauss, RJ Webby, RG Webster and MM Feeroz, 2017. Role of domestic ducks in the emergence of a new genotype of highly pathogenic H5N1 avian influenza A viruses in Bangladesh. Emerging Microbes \& Infections, 6: e72.

Bingham J, DJ Green, S Lowther and J Klippe, 2009. Infection studies with two highly pathogenic avian influenza strains (Vietnamese and Indonesian) in Pekin ducks (Anas platyrhynchos), with particular reference to clinical disease, tissue tropism and viral shedding. Avian Pathol., 38: 267-278.

Fouchier RAM, V Munster and A Wallensten, 2005. Characterization of a novel influenza A virus hemagglutinin subtype (H16) obtained from black-headed gulls. J. Virol., 79: 660-667.

Gilbert M, P Chaitaweesup, T Parakamawongsa, S Premashthira, T Tiensin, W Kalpravidh and J Slingenbergh, 2006. Free-grazing ducks and highly pathogenic avian influenza, Thailand. Emerg. Infect. Dis., 12: 227- 234

Hassan MZ, BC Das, MS Mahmud, MA Amin, MA Yousuf, M Jaber, SMSH Belal, MA Hasan, MR Karim, MS Rahman and MF Hoque, 2015. Seroprevalence and Detection of Avian Influenza Type A in Ducks at Nikli And Bajitpur Upazila of Bangladesh. Bangl. J. Vet. Med., 13: 11-17.

Islam MZ, S Ahmed, SA Khan and MB Hossain, 2012. Significance of duck in the transmission of avian influenza virus. University Journal of Zoology, Rajshahi University, 30: 77-79.

Khatun A, M Giasuddin, KM Islam, S Khanom, MA Samad, MR Islam and MM Rahman, 2013. Surveillance of avian influenza virus type A in semi-scavenging ducks in Bangladesh. BMC Veterinary Research, 9: 196.

Livestock Economy (2016-17), Department of Livestock Services, Bangladesh

Marco MAD, E Foni, L Campitelli and M Delogu, 2005. Influenza virus circulation in wild aquatic birds in Italy during H5N2 and H7N1 poultry epidemic periods (1998 to 2000). Avian Pathol., 34: 480-485. 
Second National Avian and Pandemic Influenza Preparedness and Response Plan, Bangladesh, 2009-2011, Directorate General of Health services, Bangladesh

Senne DA, DL Suarez, JC Pedersen and B Panigrah, 1994-2001. Molecular and Biological Characteristics of H5 and H7 Avian Influenza Viruses in Live-Bird Markets of the Northeastern United States. Avian Dis., 47:898-904.

Songserm T, R Jam-on, N Sae-Heng, N Meemak, DJ Hulse-Post, KM Sturm-Ramirez and WG Webster, 2006. Domestic ducks and H5N1 influenza epidemic, Thailand. Emerg. Infect. Dis., 12: 575-581.

Vander Goot JA, G Koch, MCM De Jong and M Van Boven, 2003. Transmission dynamics of low and high pathogenicity A/chicken/Pennsylvania/83 avian influenza viruses. Avian Dis., 47: 939-941. 